\title{
Memória, história e mulheres de direita na ditadura no Brasil
}

\author{
Memory, history and right-wing women \\ in the dictatorship in Brazil
}

Christiane Jalles de Paula

\section{Direitas em movimento: a Campanha da Mulher pela Democracia e a ditadura no Brasil. Fanaina Martins Cordeiro. Rio de Faneiro: Editora FGV, 2009.}

Há uma corrente na historiografia brasileira que propõe a revisão das interpretações sobre o regime militar, e especialmente a da memória construída da resistência da sociedade brasileira à ditadura. Esse movimento tem trazido novos ângulos, fontes e objetos para a compreensão do Brasil no período de 1964 a

Christiane Jalles de Paula é doutora em Ciência Política pelo IUPERJ, professora e pesquisadora do CPDOC/ FGV, Rio de Janeiro, Brasil (christiane.jalles@fgv.br).

Resenha recebida em 2 de abril de 2012 e aprovada para publicação em 4 de abril de 2012. 
1985. O trabalho de Janaína Martins Cordeiro, originalmente dissertação de mestrado defendida junto ao Programa de História da Universidade Federal Fluminense (UFF), alia-se a essa corrente. Como bem realçou Denise Rollemberg no prefácio, um dos seus méritos é que avança ao propor uma interpretação original sobre a atuação de um grupo manifestamente a favor do regime instaurado em 1964: a Campanha da Mulher pela Democracia (Camde). Por isso mesmo, não surpreende que o trabalho tenha sido agraciado com o Prêmio Pronex/UFF em 2009, que subsidiou sua publicação.

O livro Direitas em movimento: a Campanha da Mulher pela Democracia e a ditadura no Brasil assume dois objetivos. O primeiro é a recuperação da memória das mulheres da Camde, buscando, ao fazê-lo, desmistificar a memória da resistência da sociedade brasileira, uma vez que é inegável a ressonância que os discursos anticomunistas dos grupos de mulheres tiveram em 1964. O outro é entender como esses grupos apoiaram e legitimaram o golpe e a ditadura. Este é o ponto que considero mais instigante e original, uma vez que compartilho da ideia de que só podemos entender um determinado período se nos debruçarmos sobre o jogo social, político e cultural jogado pelos segmentos sociais. O livro nos permite entrever o dinamismo do jogo do qual participaram as mulheres da Camde, embora, é preciso reconhecer, nem sempre as ambiguidades tenham sido sublinhadas, e se tenha tentado, antes, encontrar as coerências do grupo. De toda forma, o livro nos leva a entender, como diz Rosanvallon (2010: 76), "o modo por que os indivíduos e os grupos elaboraram a compreensão de suas situações; os rechaços e as adesões a partir dos quais eles formularam seus objetivos; a maneira pela qual suas visões de mundo limitaram e organizaram o campo de suas ações".

Organizado em três capítulos, além da introdução e das considerações finais, o livro traz a história da Camde, os valores que forjaram a militância da entidade e, finalmente, a memória elaborada pelas militantes do grupo.

O primeiro capítulo retrata a história da Camde. Nele, a narrativa cronológica é subsumida ao tema da cultura política, o que enriquece a argumentação. Por isso mesmo, o capítulo trata das formas de organização política e das ações empreendidas pelo grupo. Há uma dupla intenção no estudo desses aspectos: compreender a ditadura e o universo simbólico do grupo. A autora nos persuade de que o grupo compartilhava uma cultura política caracteristicamente elitista, udenista, assistencialista e católica.

No capítulo 2 são apresentados os valores que nortearam a organização e a atuação da Camde. Chamando a atenção para como as mulheres do grupo fizeram uso das categorias da esfera privada (mães, esposas e donas de casa) na construção de seus discursos públicos, a autora nos traz um retrato das relações de gênero no Brasil, que mostram ser um elemento fundamental para a compreensão da participação do grupo na cena pública brasileira entre 1962 e 1974. 
No capítulo 3 são analisadas as memórias elaboradas pelas militantes da Camde. Seus silêncios, suas recusas e as dificuldades para conseguir entrevistá-las - de 17 mulheres que foram encontradas e contactadas, só quatro se dispuseram a prestar depoimento à autora - expõem a força da construção da memória do silêncio. Partindo da elaboração de Pierre Laborie, para quem o silêncio sobre determinado evento pode estar relacionado à incompreensão no presente de um comportamento do passado, a autora, ao tratar os depoimentos, constrói a teia de adesões e rechaços que marcam a memória e a história de militância das mulheres que estiveram ligadas à Camde.

O trabalho de Janaína Martins Cordeiro suscita muitas questões. Nesta resenha quero chamar atenção para três em especial.

Primeira: como tratar de um grupo de militantes católicos sem considerar a centralidade do catolicismo como "visão de mundo" (Karl Mannheim, 1982), ou seja, entender que o catolicismo estrutura uma série de vivências ou de experiências que, por sua vez, constitui-se como base comum das experiências que perpassam a vida de múltiplos indivíduos. No trabalho, embora inúmeras vezes o catolicismo seja mencionado, acabou sendo pouco explorado enquanto base comum das vivências e experiências das mulheres da Camde.

Segunda: a democracia é um conceito polissêmico. Então, não seria preciso explicitar o conceito de democracia usado pela Camde? Vale lembrar que o catolicismo, já no século XIX, adotara politicamente a si mesmo como terceira via à democracia liberal e ao socialismo, que, com a eclosão da Segunda Guerra Mundial, passou a ser chamada de "democracia cristã". Além disso, a "democracia" no catolicismo tem significado diverso daquele difundido pela democracia liberal-representativa. Não é por acaso que tan to o anticomunismo como o antiliberalismo são bases importantes do pensamento político católico.

Terceira: em vários momentos do trabalho o grupo é caracterizado como conservador. Por que não matizar este qualificativo, mostrando que, em algumas conjunturas, o grupo assumiu feição tradicionalista e, em outras, reacionária? Um investimento maior nas diferenças destes conceitos poderia nos dar indícios mais robustos dos porquês de algumas das escolhas e, principalmente, poderia realçar ainda mais as ambiguidades das mulheres da Camde.

Gostaria de finalizar ressaltando que estas considerações só reforçam a qualidade e a originalidade da interpretação. Trata-se de um livro que muito contribui para o atual debate sobre a ditadura no Brasil e que merece leitura atenta. 


\section{Referências bibliográficas}

MANNHEIM, Karl. Structures of thinking. Collected Works Volume Ten. London: Routledge + Kegan Paul, 1982.

ROSANVALLON, P. Por uma história conceitual do político. In: Por uma história do político. Tradução de Christian Edward Cyrill Lynch. São Paulo: Alameda, 2010. 